\title{
Soil Erosion around Foundations of Houses in Four Communities in Ghana
}

\author{
Kofi Agyarko*, Joseph Adu, Daniel Gyasi, Samuel Kumi, Lydia Mensah \\ College of Agriculture Education, University of Education, Winneba, Ghana. \\ Email: *agyarkokofi@yahoo.com
}

Received December $20^{\text {th }}, 2011$; revised January $23^{\text {rd }}$, 2012; accepted February $4^{\text {th }}, 2012$

\begin{abstract}
Soil erosion studies around houses in four communities in Ghana were carried out from August to November, 2010. Thirty houses were selected from each of the four communities for the study. Measurements of slope and the depth of exposed foundation of houses were done with the help of a string and a tape measure. Data were also obtained through questionnaire and interview of house owners. The Pearson's correlation coefficient was used to measure some relationships among data. In the selection of site for building a house, higher percentage of the house owners considered no factor. The major cleaning activity around the surrounding of houses was noted to be sweeping with a broom. All the houses in the communities had their foundations exposed, $57 \%-93 \%$ of the houses had exposed foundations up to a level within 51 - $100 \mathrm{~cm}$ which was classified as "Severely Exposed". The extent of building foundation exposed by soil erosion was found to be positively correlated with the age of building and the slope of the land. Most of the respondents controlled soil erosion by blocking water ways with materials such as, sand heaps, stones and sacks filled with soil. Only $10 \%$ of the respondents from one of the communities planted grasses around their houses to control soil erosion. Communities need to be educated to plant grasses around their houses to beautify the surroundings and to control soil erosion.
\end{abstract}

Keywords: Soil Erosion; Foundations; Houses; Exposed

\section{Introduction}

Soil, a thin layer that covers most of the earth's land surface might appear insignificant relative to the bulk of the earth, yet it is in this thin layer of soil that living kingdoms establish a dynamic relationship [1]. Soil is an important natural resource which is vital for all living organisms as major ecosystems, as well as for food production, development and growth of settlements and population distribution. However, this layer is gradually being destroyed from its natural state through erosion as a result of man's activities in searching for a better living condition. Soil erosion causes tremendous damage to about one-third of world's cropland [2].

Global Assessment of Soil Degradation (GLASOD) study estimated that about 15 per cent of the earth's icefree land surface is afflicted by all forms of land degradation. Of this, accelerated soil erosion by water is responsible for about 56 per cent and wind erosion is responseble for about 28 percent. This means that the area affected by water erosion is, around 11 million square $\mathrm{km}$, and the area affected by wind erosion is around 5.5 mil-

${ }^{*}$ Corresponding author. lion square $\mathrm{km}$ [3].

About $80 \%$ of the World's agricultural land suffers moderate to severe erosion and $10 \%$ suffers slight to moderate erosion. Soil erosion rates may exceed 100 ton per ha per year in severely overgrazed pastures [4].

Effects of erosion are enormous. At the household level, the onsite effects include damages to buildings, damages to drains and roads, destruction of landscape, and causing of flood. Erosion exposes building foundations which warrant routine repair of houses. In some cases erosion causes complete collapse of buildings and those buildings must be rebuilt and this adds to the expenditure of poor households. Sometimes erosion renders households homeless if houses collapse [5].

Some houses in older communities of Ghana are observed to have their foundations dangerously exposed by soil erosion. The paper attempts to assess the extent of soil erosion of foundation of houses and the steps taken to solve this problem by house owners in four communities in Ghana.

\section{Materials and Methods}

The study was conducted in four communities in Ghana, 
Nkrankwanta in Brong Ahafo Region, Agona and Mampong in Ashanti Region and Asankragua in Western Region from August to November, 2010. Within each of the four communities thirty houses/buildings were randomly selected for the study. Data were obtained through the use of questionnaire and physical measurement of percentage slope and the depth of the base (foundation) of houses exposed.

The questionnaire was made up of both open ended and close ended questions. Age of respondents, age of houses, factors considered in selecting sites for building houses, methods used to clean around houses and erosion control measures taken by house owners were the major elements of the questionnaire. The owners of the selected houses were the respondents.

The extent of foundation of a house exposed by erosion was measured from the ground level to the exposed foundation (Figure 1) with a tape measure. Measurement was taken at the part of the foundation where soil erosion seemed to be very severe.

The measurement of the slope of land at the spot of a house was done using the method described by Cowlitz County Building Planning Department [6] (Figure 2): Rise (H)/Run (D) $\times 100=$ Slope in percent.

The data were analyzed using the Statistical Package for Social Sciences (SPSS) version 11. The relationships between the extent of foundation exposure of houses and age of houses and slope of land were found using the Pearson's correlation coefficient at 5\% significance level.

\section{Results and Discussion}

As the studies were conducted in the old settlements of the communities many of the houses were found to be more than 30 years of age (Table 1). Majority of the owners of the houses studied in the four communities were above 45 years of age (Table 2) with most of them being males $(67 \%, 80 \%, 67 \%$ and $57 \%$ for Nkrankwanta, Asankragua, Mampong and Agona respectively). All the four communities were Akan speaking societies with matrilineal inheritance system. Among the matrilineal Akan, family property is inherited without subdivision, in the first instance by the oldest surviving brother. When the whole generation of siblings dies out, the estate then goes to the eldest sister's eldest son [7]. It was therefore not surprising that most of the houses were found having males as the house owners.

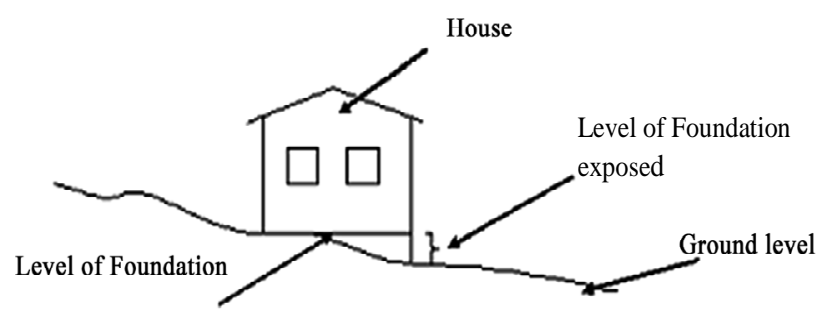

Figure 1. Measurement of the extent of foundation exposed.

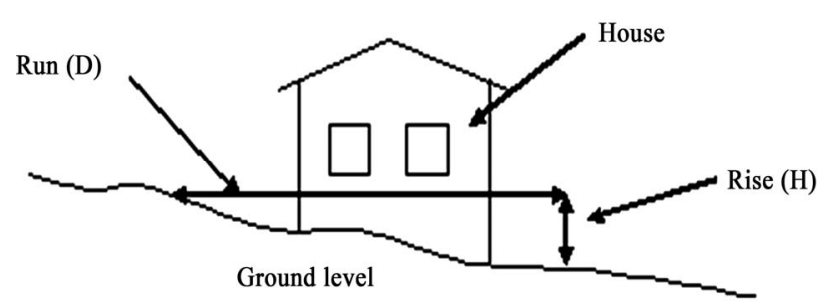

Figure 2. Measurement of slope.

Table 1. Age of houses.

\begin{tabular}{lcccccccc}
\hline & \multicolumn{7}{c}{ Community } \\
\cline { 2 - 8 } Age (Years) & Nkrankwanta & Asankragua & Mampong & & Agona \\
\cline { 2 - 9 } & Number of Houses & $\%$ & Number of Houses & $\%$ & Number of Houses & $\%$ & Number of Houses & $\%$ \\
\hline Below 10 & 1 & 3 & 0 & 0 & 1 & 3 & 3 & 10 \\
$11-20$ & 3 & 10 & 5 & 17 & 1 & 3 & 3 & 10 \\
$21-30$ & 5 & 17 & 9 & 30 & 8 & 27 & 19 & 63 \\
Above 30 & 21 & 70 & 16 & 53 & 20 & 67 & 30 & 100 \\
Total & 30 & 100 & 30 & 100 & 30 & 100 & 30 \\
\hline
\end{tabular}

Table 2. Age of owners of surveyed houses.

\begin{tabular}{lcccccccc}
\hline & \multicolumn{9}{c}{ Community } \\
\cline { 2 - 9 } $\begin{array}{l}\text { Age of Respondents } \\
\text { (Years) }\end{array}$ & \multicolumn{2}{c}{ Nkrankwanta } & \multicolumn{2}{c}{ Asankragua } & \multicolumn{2}{c}{ Mampong } & & Agona \\
\cline { 2 - 9 } & Frequency & $\%$ & Frequency & $\%$ & Frequency & $\%$ & Frequency & $\%$ \\
\hline Below 25 & 0 & 0 & 0 & 0 & 2 & 7 & 1 & 3 \\
$26-35$ & 6 & 20 & 2 & 7 & 5 & 16 & 5 & 17 \\
$36-45$ & 6 & 20 & 9 & 30 & 3 & 10 & 7 & 23 \\
Above 45 & 18 & 60 & 19 & 63 & 20 & 67 & 17 & 57 \\
Total & 30 & 100 & 30 & 100 & 30 & 100 & 30 & 100 \\
\hline
\end{tabular}


In the selection of site for building a house, higher percentage (47\%, 40\%, 53\% and 50\% for Nkrankwanta, Asankragua, Mampong and Agona respectively) of the respondents considered no factor. Only few of them considered factors as, soil type and slope (Table 3 ). With the exception of those who purchased land before building a house most of the houses especially in the old settlements were built based on the availability of family land and hence not much emphasis was laid on the factors considered. Consideration of factors prior to building a house is important as these factors may have negative or positive impact on the house and its occupants in the future [8].

The more noted cleaning activity around the houses in the communities was sweeping (60\%, 77\%, 70\% and $83 \%$ for Nkrankwanta, Asankragua, Mampong and Agona respectively) with a broom which was sometimes combined with weeding (Table 4). These major cleaning activities were seen and are still seen daily in communities in Ghana. Sweepings of these natures add high proportions of sand and stones to the communities' solid waste being carried to refuse dump sites as observed by Agyarko et al. [9]. Such removal of soil may act as precursor of soil erosion by water around houses in the communities.

Table 5 shows the level of exposure by soil erosion of foundations of houses in the communities. None of the houses was found to have its foundation exposed by 10 $\mathrm{cm}$ or less. All the houses had their foundations exposed to some degree. High percentage (60\%, 57\%, 93\% and 87\% for Nkrankwanta, Asankragua, Mampong and Agona respectively) of the houses had their foundations exposed up to a depth between $51-100 \mathrm{~cm}$ which was considered as "Severely Exposed" on the bases of the classification of the degree of exposed building foundations by the authors (Table 6).

Table 3. Factors considered in selecting site for building a house.

\begin{tabular}{lcccccccc}
\hline & \multicolumn{7}{c}{ Community } \\
\cline { 2 - 8 } Factor & Nkrankwanta & Asankragua & Mampong & & Agona \\
\cline { 2 - 9 } & Frequency & $\%$ & Frequency & $\%$ & Frequency & $\%$ & Frequency & $\%$ \\
\hline Slope & 6 & 20 & 7 & 23 & 11 & 37 & 9 & 30 \\
Soil type & 10 & 33 & 6 & 20 & 3 & 10 & 5 & 17 \\
Drainage & 0 & 0 & 5 & 17 & 0 & 0 & 1 & 3 \\
No factor & 14 & 47 & 12 & 40 & 16 & 53 & 15 & 50 \\
Total & 30 & 100 & 30 & 100 & 30 & 100 & 30 & 100 \\
\hline
\end{tabular}

Table 4. Methods used to clean the surrounding of houses.

\begin{tabular}{lcccccccc}
\hline & \multicolumn{9}{c}{ Community } \\
\cline { 2 - 8 } Cleaning Method & \multicolumn{2}{c}{ Nkrankwanta } & Asankragua & Mampong & & Agona \\
\cline { 2 - 8 } & Frequency & $\%$ & Frequency & $\%$ & Frequency & $\%$ & Frequency & $\%$ \\
\hline Sweeping & 18 & 60 & 23 & 77 & 21 & 70 & 25 & 83 \\
Weeding & 0 & 0 & 2 & 6 & 0 & 0 & 0 & 0 \\
Sweeping and weeding & 12 & 40 & 5 & 17 & 9 & 30 & 5 & 17 \\
Others & 0 & 0 & 0 & 0 & 0 & 0 & 0 & 30 \\
Total & 30 & 100 & 30 & 100 & 30 & 100 & 100 \\
\hline
\end{tabular}

Table 5. Depth of foundation of houses exposed.

\begin{tabular}{|c|c|c|c|c|c|c|c|c|c|}
\hline \multirow{3}{*}{$\begin{array}{l}\text { Depth } \\
\text { Exposed (cm) }\end{array}$} & \multicolumn{8}{|c|}{ Community } & \multirow{3}{*}{$\begin{array}{l}\text { Classification of } \\
\text { exposed depth }\end{array}$} \\
\hline & \multicolumn{2}{|l|}{ Nkrankwanta } & \multicolumn{2}{|l|}{ Asankragua } & \multicolumn{2}{|l|}{ Mampong } & \multicolumn{2}{|l|}{ Agona } & \\
\hline & Number of Houses & $\%$ & Number of Houses & $\%$ & Number of Houses & $\%$ & Number of Houses & $\%$ & \\
\hline Below 10 & 0 & 0.00 & 0 & 0.00 & 0 & 0.00 & 0 & 0.00 & Unexposed \\
\hline $10-30$ & 2 & 6.67 & 2 & 6.67 & 0 & 0.00 & 0 & 0.00 & Exposed \\
\hline $31-50$ & 7 & 23.33 & 5 & 16.66 & 2 & 6.67 & 2 & 6.67 & Highly Exposed \\
\hline $51-100$ & 18 & 60.00 & 17 & 56.67 & 28 & 93.33 & 26 & 86.66 & Severely Exposed \\
\hline Above 100 & 3 & 10.00 & 6 & 20.00 & 0 & 0.00 & 2 & 6.67 & Extremely Exposed \\
\hline Total & 30 & 100 & 30 & 100 & 30 & 100 & 30 & 100 & \\
\hline
\end{tabular}


Table 6. Classification of foundation exposure.

\begin{tabular}{ll}
\hline Depth Exposed $(\mathrm{cm})$ & Classification \\
\hline 10 & Unexposed \\
$10-30$ & Exposed \\
$31-50$ & Highly Exposed \\
$51-100$ & Severely Exposed \\
100 & Extremely Exposed \\
\hline
\end{tabular}

Most houses in the Mampong and Agona communities were found on the slope between $5 \%$ and $9 \%$, most of the houses in the other communities were found on the slope between $1 \%$ and $5 \%$ (Table 7). Though foundation of houses may be exposed by soil erosion with time if proper measures are not put in place, the slope of the land is a major factor to be given a critical consideration. The slope therefore could have attributed to the percentage differences of the number of houses with their foundations considered "Severely Exposed" among the communities-93\% and 87\% for Mampong and Agona communities respectively and $60 \%$ and $57 \%$ for Nkrankwanta and Asankragua communities respectively (Table $5)$.

The extent of building foundation exposed by erosion was found to be positively correlated with the age of building and the slope of the land (Table 8).The slope had a higher positive correlation figure than the age of the building. Slope is considered to be a critical factor in determining soil erosion and fields with slopes of 10 - 15 per- cent slopes will likely be very prone to erosion [10]. Though, almost all the houses in the communities were built on land slopes of less than 9\%, and may be considered less prone to soil erosion, the length of the slope which is also another critical factor in determining soil erosion could cause even a constant slope of 2 percent to erode severely [10].

Measures taken to control soil erosion around houses in the communities therefore are imperative to prevent collapse of houses which may lead to death of human beings. Apart from the respondents in Mampong where only $27 \%$ control soil erosion in their community more than half (53\%, 60\% and 67\% for Nkrankwanta, Asankragua and Agona respectively) of the respondents in the other communities control soil erosion (Table 9). Table 10 shows the various soil erosion control measures embarked by the communities. From the table it is observed that more than half $(75 \%, 61 \%, 75 \%$ and $50 \%$ for Nkrankwanta, Asankragua, Mampong and Agona respectively) of the respondents controlled soil erosion by blocking water ways with materials such as, sand heaps, stones and sacks filled with soil. Few of the respondents redirected the flow of running water. Though planting of grasses has been found to be effective in soil erosion control, only $10 \%$ of the respondents from Agona community planted grasses around their houses to control soil erosion, the rest of the communities did not embark on this control measure and even weeded any kind of vegetation around their houses.

Table 7. Percentage slope.

\begin{tabular}{|c|c|c|c|c|c|c|c|c|}
\hline \multirow{3}{*}{ Slope (\%) } & \multicolumn{8}{|c|}{ Community } \\
\hline & \multicolumn{2}{|c|}{ Nkrankwanta } & \multicolumn{2}{|c|}{ Asankragua } & \multicolumn{2}{|l|}{ Mampong } & \multirow{2}{*}{$\begin{array}{r}\text { Agona } \\
\text { Number of Houses }\end{array}$} & \multirow[b]{2}{*}{$\%$} \\
\hline & Number of Houses & $\%$ & Number of Houses & $\%$ & Number of Houses & $\%$ & & \\
\hline Below 1 & 0 & 0 & 0 & 0 & 0 & 0 & 0 & 0 \\
\hline $1-3$ & 20 & 67 & 18 & 60 & 1 & 3 & 0 & 0 \\
\hline $3-5$ & 10 & 33 & 7 & 23 & 2 & 7 & 1 & 3 \\
\hline $5-7$ & 0 & 0 & 5 & 16 & 10 & 33 & 11 & 37 \\
\hline $7-9$ & 0 & 0 & 0 & 0 & 11 & 37 & 14 & 47 \\
\hline Above 9 & 0 & 0 & 0 & 0 & 6 & 20 & 4 & 13 \\
\hline Total & 30 & 100 & 30 & 100 & 30 & 100 & 30 & 100 \\
\hline
\end{tabular}

Table 8. Correlation between the extent of foundation exposure of houses and age of houses and slope of land.

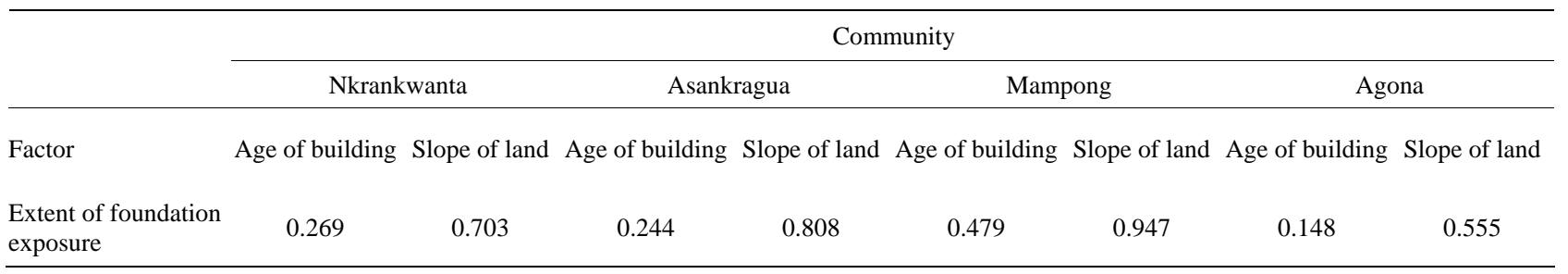


Table 9. Responses to the control of soil erosion.

\begin{tabular}{lcccccccc}
\hline & \multicolumn{9}{c}{ Community } \\
\cline { 2 - 8 } Response to erosioncontrol & \multicolumn{1}{c}{ Nkrankwanta } & \multicolumn{2}{c}{ Asankragua } & & Mampong & & Agona \\
\cline { 2 - 8 } & Frequency & $\%$ & Frequency & $\%$ & Frequency & $\%$ & Frequency & $\%$ \\
\hline Control erosion & 16 & 53 & 18 & 60 & 8 & 27 & 20 & 67 \\
Do not control erosion & 14 & 47 & 12 & 40 & 22 & 73 & 10 & 33 \\
Total & 30 & 100 & 30 & 100 & 30 & 100 & 30 & 100 \\
\hline
\end{tabular}

Table 10. Erosion control measures.

\begin{tabular}{|c|c|c|c|c|c|c|c|c|}
\hline \multirow{3}{*}{ Erosion control measure } & \multicolumn{8}{|c|}{ Community } \\
\hline & \multicolumn{2}{|c|}{ Nkrankwanta } & \multicolumn{2}{|c|}{ Asankragua } & \multicolumn{2}{|c|}{ Mampong } & \multicolumn{2}{|c|}{ Agona } \\
\hline & Frequency & $\%$ & Frequency & $\%$ & Frequency & $\%$ & Frequency & $\%$ \\
\hline Redirection of water ways & 4 & 25 & 7 & 39 & 2 & 25 & 8 & 40 \\
\hline Block water ways & 12 & 75 & 11 & 61 & & 75 & 10 & 50 \\
\hline Planting grasses & 0 & 0 & 0 & 0 & 0 & 0 & 2 & 10 \\
\hline Total & 16 & 100 & 18 & 100 & 8 & 100 & 20 & 100 \\
\hline
\end{tabular}

\section{Conclusions and Recommendations}

All the houses in the communities had their foundations exposed, with higher number of them being severely exposed. Efforts were made by the communities to control soil erosion around their houses through blocking of water ways with materials such as, sand heaps, stones and sacks filled with soil, however, planting of grasses in the surrounding of houses was almost absent, surrounding of houses were seen bare without any kind of vegetation.

Communities should be encouraged to plant grasses around their houses to beautify the surroundings and to control soil erosion.

Alternative cleaning methods around the houses should be considered in the communities as the sweeping and weeding methods adopted by the communities carry soil away and induce soil erosion.

\section{REFERENCES}

[1] F. R. Troeh and L. M. Thompson, "Soils and Soil Fertility,” Blackwell Publishing Ltd., Oxford, 2005.

[2] N. W. Hudson, “Soil Conservation,” B.T Brantford Ltd., London, 1989.

[3] D. Favis-Mortlock, “The Extent of Soil Erosion,” 2005. http://soilerosion.net/doc/extent_of_erosion.html

[4] D. Pimentel, C. Harvey, P. Resosudarmo, K. Sinclair, D. Kurz, M. McNair, S. Crist, L. Shpritz, L. Fitton, R. Saf- fouri and R. Blair, "Environmental and Economic Costs of Soil Erosion and Conservation Benefits," Science, New Series, Vol. 267, No. 5201, 1995, pp. 1117-1123. doi:10.1126/science.267.5201.1117

[5] J. Gyamfi-Aido and R. G. Congalton, “Application of GIS to the Assessment of Land Degradation and Associated Hazards in the Upper East Region of Ghana,” Proceedings of 2nd International Conference, Extracts and Workshop on GIS, San Francisco, 26-30 October 1987, pp. 487-497.

[6] Cowlitz County Building Planning Department, "Calculating Slope,” 2008.

http://www.co.cowlitz.wa.us/buildplan/forms/Calculating \%20Slope

[7] Advameg, "Countries and Their Culture — Culture of Ghana -History, People, Clothing, Traditions, Women, Beliefs, Food, Customs, Family,” 2011.

http://www.everyculture.com/GeIt/Ghana.html\#ixzz1bbv 67slj

[8] Permalink, “Home Building Remodeling,” 2008. http://www.homebuildingremodeling.com/cgi-bin/mt-tb.c gi/6

[9] K. Agyarko, E. O. Akoto, and A. Awuah, "Characterization of Solid Wastes Generated by a Community in Ghana -The Case of Asante Mampong," Journal of Applied Science and Technology, Vol. 12, No. 1-2, 2007, pp. 46-51.

[10] Google’s Cache, "Factors Affecting Soil Erosion,” 2011. http://www.spindigo.com/doctorluke/www/Transcripts/ag riculture_eng/2_10_soil_erosion_factors.htm. 